\title{
economics-of-security.eu
}

Jitka Malečková and Dragana Stanišić

\section{Public Opinion and Terrorist Acts}

April 2010

Economics of Security Working Paper 32

This publication is an output of EUSECON, a research project supported by the European Commission's Seventh Framework Programme.

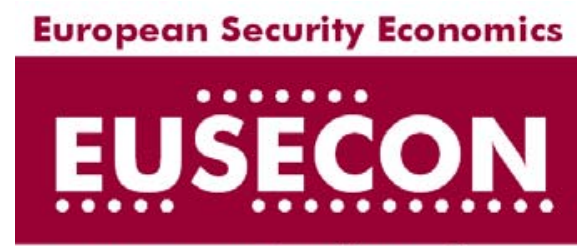

www.economics-of-security.eu

Economics of Security is an initiative managed by DIW Berlin 


\section{Economics of Security Working Paper Series}

Correct citation: Malečková, J. and Stanišić, D. (2010). "Public Opinion and Terrorist Acts". Economics of Security Working Paper 32, Berlin: Economics of Security.

First published in 2010

(C) Jitka Malečková and Dragana Stanišić 2010

ISSN: $1868-0488$

For further information, please contact:

Economics of Security, c/o Department of International Economics, German Institute for Economic Research (DIW Berlin), Mohrenstr. 58, 10117 Berlin, Germany.

Tel: $+49(0) 3089789-277$

Email: eusecon@diw.de

Website: www.economics-of-security.eu 


\title{
Public Opinion and Terrorist Acts
}

Jitka Malečková and Dragana Stanišić ${ }^{1}$

\begin{abstract}
The paper explores the dimensions of public opinion relevant for supporting terrorism and their relationship with terrorist attacks. We link the 2007 PEW survey data on justification of suicide terrorism and opinions in 16 countries of the Middle East, Africa and Asia on nine regional powers to the NCTC data on international terrorist incidents between 2004 and 2008. We find that justification of suicide terrorism and unfavorable opinion on regional powers are correlated with the occurrence of terrorism and the effect of each of these dimensions of public opinion varies with the level of the other. In addition, we find a robust positive relationship between the share of people in a country who at the same time justify suicide bombings and have an unfavorable opinion of a regional power and the occurrence of terrorism originating from that country.
\end{abstract}

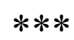

Key words: support for terrorism, public opinion, international terrorism Number of JEL code

\footnotetext{
${ }^{1}$ CERGE-EI, Charles University in Prague dragana.stanisic@ecerge-ei.cz tel. (+420) 224005227 fax. (+420) 224005333
} 
Preventing terrorism is a multi-faceted effort. The selection of appropriate means and areas on which to focus this effort is complicated by a lack of agreement among scholars and analysts regarding the causes of terrorism. Recently, scholars have paid increasing attention to the importance of public support for terrorism as a factor influencing the selection of terrorists' methods and their decision to end terrorist campaigns and as a pool of potential recruits (Merrari 2005; Katzenstein and Keohane 2006; Gurr 1998). However, few empirical studies examine the relationship between public opinion and terrorist acts and the mechanism of how public opinion relates to terrorist activity remains unclear. If a connection can be established between public opinion and occurrence of terrorism then efforts to prevent or limit terrorist incidents should meaningfully focus on influencing public opinion among the relevant populations. Concurrently, it would be helpful to determine which dimensions of public opinion matter for the occurrence of terrorism.

In a recent article, Alan Krueger and one of the authors of the present paper have examined the effect of public opinion in one country toward another country on the number of terrorist attacks perpetrated by individuals or groups from the former country against targets from the latter country (Krueger and Malečková 2009). Linking data from the Gallup World Poll from Middle Eastern and North African countries on the performance of the leaders of nine world power to the NCTC data on the number of terrorist events, we found a greater incidence of international terrorism when people of one country disapprove of the leadership of another country.

The aim of this paper is to get a more nuanced view of the dimensions of public opinion that may be relevant for supporting terrorism and check the finding of the previous paper about the relationship between public opinion and occurrence of terrorism using different data. We focus on two dimensions of public opinion: The first dimension, opinion of regional powers, expresses the attitude to a country or group of countries that can be considered responsible for regional policy and status quo; this attitude can be shaped and mobilized in a conflict (or terrorist campaign). The second dimension of public opinion that we analyze, justification of suicide terrorism, expresses support for extreme violence and for terrorism as a means of solving conflicts. 
As is common in terrorism research, it is difficult to find systematic data that would cover a longer period and a larger set of countries, and keep the survey questions consistent. We use the 2007 PEW survey and specifically the information on justification of suicide terrorism and opinions in 16 countries of the Middle East, Africa and Asia on nine regional powers. We then link these data to the NCTC data on international terrorist attacks between 2004 and 2008.

We find a wide variation among individual countries concerning both questions. We also find that opinion on regional powers and justification of suicide terrorism are independent. Our analysis suggests that justification of suicide terrorism and unfavorable opinion on regional powers are correlated with the occurrence of terrorism and the effect of each of these dimensions of public opinion varies with the level of the other. In addition, we find a robust positive relationship between the share of people in a country who at the same time justify suicide bombings and have an unfavorable opinion of a regional power and the occurrence of terrorism originating from that country. This has implications for security policy as the dimensions of public opinion respond differently to propaganda (whether by states or extremist groups) and may be influenced by different means.

After a brief description of the data, we provide an overview of the justification rates of suicide terrorism and opinions of nine regional powers in 16 countries of the Middle East, Africa and Asia. We then examine the relationship between the two dimensions of public opinion and the effect of these dimensions on the occurrence of terrorism originating from the 16 countries and targeted against the nine regional powers. We conclude with interpretations of our results and their implications for policy and for further research.

\section{Data}

We use data on public opinion from the PEW Global Attitudes Project, specifically the survey issued in June, 2007 - Pew Global Attitudes Project: Spring 2007 Survey, concerning 16 countries in the Middle East, Africa and Asia with large Muslim populations. The PEW surveys belong among the most useful databases for the study of public opinion and political violence or terrorism because some of the surveys include a large set of countries and the same survey questions are sometimes repeated over time (unfortunately not always and not always in the same countries). The PEW public opinion surveys are 
nationally representative. ${ }^{2}$ In the 2007 survey, only in Pakistan the samples chosen were urban. In most countries, ${ }^{3}$ face-to-face interviews were conducted in local languages and most of the surveyed population were adults (above 18).

Among the Survey questions that could be relevant for the study of terrorism, we selected two questions that tap into different aspects of public opinion: first, attitudes towards powers that may be seen as affecting the fate of a country and the whole region, and, second, attitudes towards (suicide) terrorism.

The first dimension of public opinion is represented by the following question: Please tell me if you have a very favorable, somewhat favorable, somewhat unfavorable or very unfavorable opinion of: (country)? The particular countries (or groups of countries) about which this question was asked were: China, Egypt, ${ }^{4}$ the European Union, India, Iran, Japan, Russia, Saudi Arabia and the United States. We refer to these countries as countries Y. We construct a variable "Opinion", which is the percentage of those in a country who have somewhat unfavorable and very unfavorable opinion of country Y.

The exact phrasing of the second question is: Some people think that suicide bombing and other forms of violence against civilian targets are justified in order to defend Islam from its enemies. Other people believe that, no matter what the reason, this kind of violence is never justified. Do you personally feel that this kind of violence is often justified to defend Islam, sometimes justified, rarely justified, or never justified? This question can be considered problematic as it conflates terrorism and suicide terrorism. ${ }^{5}$ Yet, it reflects approval/disapproval of the use of extreme forms of violence and terrorist means and has been utilized in research to study support for terrorism (Fair and Shepherd 2006).

For the purpose of our analysis we include all the countries where this particular question was asked, namely Bangladesh, Egypt, Ethiopia, Kuwait, Malaysia, Morocco, Senegal, Tanzania, Mali, Jordan, Lebanon, Indonesia, Turkey, Pakistan, Palestine and Nigeria. We refer to these countries as countries X. The possible answers to the question were: often justified, sometimes justified, rarely justified and never

\footnotetext{
${ }^{2}$ The sample sizes were as follows: Kuwait 500; Malaysia 700; Mali and Senegal 700; Tanzania 704; Ethiopia 710; Palestine Territories 808; Turkey 971; Bangladesh, Egypt, Jordan, Lebanon, Morocco 1,000; Indonesia 1,008; Nigeria 1,128 and Pakistan 2,008.

${ }^{3}$ Except in Kuwait where face-to-face interviews were combined with interviews via telephone.

${ }^{4}$ We excluded the Egypt - Egypt pair.

${ }^{5}$ For a discussion on this question, see Fair and Shepherd 2006.
} 
justified. We construct a variable "justification rate" by combining the answers "often justified" and "sometimes justified" and use these answers to construct the rate that represents the percentage of the population that justifies suicide bombing. ${ }^{6}$

We measure terrorism through the number of international terrorist incidents that occurred from 2004 to 2008 as collected by the National Counterterrorism Center (NCTC). In the NCTC Worldwide Incidents Tracking System (WITS) a terrorist incident is defined as an incident "in which subnational or clandestine groups or individuals deliberately or recklessly attacked civilians or noncombatants (including military personnel and assets outside war zones and war-like settings)" (The Worldwide Incidents Tracking System). As source countries of terrorist attacks, we use the same group of countries that were included in the public opinion survey (countries X). Since we focus on international terrorism we selected only those incidents where the data show that the perpetrator and the victim were from different countries. In particular, we consider incidents where perpetrators are from countries $\mathrm{X}$ and targets (people or property) from countries Y.

We created the units of observation by making pairs of countries (n_pairs $=X \cdot Y)$ (Krueger and Malečková 2009). Not all countries X were asked about countries Y; in total, we created 121 pairs. ${ }^{7}$ However, given that the Pakistan and India pair with 310 recorded incidents is an outlier in the sample, we excluded this pair from further analysis.

We are aware that there is no established production function of terrorism and therefore we rely on models in previous studies in order to measure the effect of public opinion on terrorism. Apart from public opinion, we control for economic, institutional and geographic characteristics (Table 1). For GDP per capita we use the World Bank Development Indicators datasets and calculate the average GDP per capita from 2002 to 2006. A specific case was the question regarding the European Union since it is not a country, though it can be considered a regional power. For the purpose of calculating the GDP,

\footnotetext{
${ }^{6}$ The data were provided with the weights so the adjustments were done for the missing responses and the answers are weighted and represent a part of the total $100 \%$.

${ }^{7}$ Source countries are those where the question regarding the justification of suicide bombing was asked; target countries are those about which the opinion was asked in the source countries.
} 
population and civil liberties, we calculated averages of countries that we assigned to the group E.U. (Germany, France, Belgium, UK, Spain, Italy, Luxemburg and Netherlands). ${ }^{8}$

We also use the World Bank Development Indicators datasets for information about the population. We use data on civil liberties provided by the Freedom House's dataset. The civil liberties index ranges from 1 to 7 , where 7 represents a total lack of civil liberties. Data on religion (specifically the percentage of Muslims in the country) are taken from the CIA Factbook. Geographical characteristics such as distance between the originating and target capital cities $^{9}$ are calculated using Haversine formula and the available online converter. ${ }^{10}$

\section{Public opinion}

Analysts studying existing terrorist cells, economists as well as psychologists have emphasized the importance of public opinion for terrorism. Terrorists are well aware of the relevance of public opinion and plan their attacks accordingly, e.g. choosing the time, location or target that would make the strongest impact on the public (Hassan 2006; Krueger 2007). Some studies have also suggested that terrorist attacks affect public opinion, e.g. regarding voting in Israel (Berrebi and Klor 2006). While the effects of terrorist incidents on public opinion should be kept in mind, scholars agree that public opinion matters for terrorism. Its role ranges from legitimizing terrorist acts and selecting specific methods and tools, to functioning and even survival of terrorist groups, to decreasing the costs of attacks and recruiting new terrorists. Some scholars even suggest that the process of radicalization goes from holding positive views on terrorism through supporting terrorist groups and finally joining these groups (Alonso 2006). Assuming that the impact of public opinion on terrorism is indeed relevant, it is useful to find what dimensions of public opinion are pertinent and on which to focus the efforts to prevent terrorism.

In the paper with Alan Krueger, the negative views that appeared relevant for the occurrence of terrorism concerned the performance of leaders of world powers. In this paper, we look at opinions

\footnotetext{
${ }^{8}$ We selected these countries as the oldest and leading members of the E.U. This fact goes in line with the collection of data on the terrorist incidents against these countries in the period from 2004 to 2008.

${ }^{9}$ Brussels was taken as a capital city of the European Union.

${ }^{10}$ www.codecodex.com
} 
about nine countries that can be considered regional powers and represent both different cultures and a wide range of stands in international policy. Research on anti-Americanism suggests that perceptions of a country are rather complex and consist of both positive and negative attitudes (Katzenstein and Keohane 2006). In the case of opinions of the United States in Muslim countries, positive attitudes towards American culture and society are shown to go together with negative attitudes towards American policies (Chiozza 2006). The negative attitudes towards those considered responsible for the political and economic situation are suggested to foster support for terrorism (Tessler and Robbins 2007). This is relevant because if support for terrorism reflects essentialist and deeply entrenched views of certain countries, cultures or religions and terrorists simply "hate us" (usually meaning the Western world) regardless of "our" actual policies, accommodating the grievances of the populations that the terrorists claim to represent (while possibly a worthwhile act in itself) would not lead to a decrease in terrorism. If, in contrast, support for terrorism responds to the political situation and its changes, reconsidering political directions may have a direct impact on the intensity of terrorism.

The second dimension of public opinion we analyze, justification of suicide terrorism as an extreme form of violence and means of achieving goals, has been used in past research to study the support for terrorism particularly in the Middle East. Scholars have looked at individual level data, focusing on the demographic characteristics of the respondents, their religious beliefs and psychological characteristics (Tessler and Robbins 2007; Fair and Shepherd 2006; Victoroff et al. 2006; Malečková 2006). This research, however, did not explore the conditions under which justification of suicide terrorism decreases or increases and its relationship with the occurrence of terrorism. Other studies point out the relevance of the approval of extreme forms of violence as a precondition for joining a terrorist group. A study of the IRA and ETA shows that those who became members of the two organizations had previously believed that extreme violence is useful and would help advance their goals (Alonso 2006). ${ }^{11}$ This makes the analysis of justification of suicide terrorism particularly relevant for research that tries to link public opinion to the occurrence of terrorism.

Our analysis shows a large variety of views on both questions among the 16 countries. A detailed overview of the low and high unfavorable opinions across the 16 countries is in Table 2, although the

\footnotetext{
${ }^{11}$ Although the IRA and ETA engage in domestic terrorism, the same logic of recruitment is likely to be at work in groups that focus on international terrorism, not to mention that terrorist organizations often attack both domestic and foreign targets.
} 
questions about opinions on every one of the nine powers were not asked in all the 16 countries. The opinions about the regional powers vary from a high average of 0.53 concerning the U.S., to somewhat less negative opinions on the Russian Federation (0.39), Iran (0.37), India (0.36) and the European Union (0.31), to the least unfavorable/most favorable views on China (0.26), Egypt (0.25), Japan (0.20) and Saudi Arabia ${ }^{12}$ (0.17) (Table 3). Palestinians hold the most unfavorable views of the U.S. (0.86), while the least unfavorable views on the U.S. are expressed in Mali (0.18). Interestingly, the most negative views on the Russian Federation (0.64), China (0.53) and Saudi Arabia (0.39) are held by the Turks who also have the highest average of unfavorable views on the nine countries (0.52). Palestinians follow with the average of 0.5 ; they express the most unfavorable views on the U.S. among the 16 countries (reaching 0.86) and, among the nine regional powers, hold the most favorable opinions on Saudi Arabia (0.33). The following group of high unfavorable averages includes Jordan (0.46), Lebanon (0.43) and Egypt (0.43) (Table 4). These opinions are in themselves interesting, but not terribly surprising.

The justification of suicide terrorism presents a more intriguing variation. Across the 16 countries we find that, on average, $23 \%$ of the surveyed population justifies suicide bombing (Table 2). The percentage of those who say that suicide terrorism is often or sometimes justified was, in 2007, highest in Palestine, followed by Nigeria and Mali. The percentage was lowest in Egypt, followed by Pakistan and Indonesia. These results, particularly the high justification rate in Mali and low justification of suicide terrorism in Egypt, Pakistan and Indonesia, seem surprising (Figure 1). The order of the countries does not change significantly if we only include the most extreme views, i.e. the percentage of those who answered that justification of suicide bombing is "Often Justified".

In order to explain this variation, we looked at the demographic characteristics of those who believe that terrorism is sometimes or often justified and those who believe that it is rarely or never justified and compared the views on suicide terrorism with previous findings. We performed a pair-wise t-test of Justification according to gender (For details see Appendix 2). Gender does not seem to play a significant role in the justification rates overall, but in some countries differences among men and women are noticeable. The differences are large in Morocco, followed by Pakistan, Nigeria, Turkey, Indonesia and Senegal. While according to the 2002 PEW survey (Fair and Shepherd 2006, Malečková

\footnotetext{
${ }^{12}$ Saudi Arabia was not asked in all countries, while Japan was.
} 
2006), women did not appear as more peaceful than men, in 2007, men justified suicide terrorism more often then women in most countries, including Turkey, Senegal, Indonesia and particularly Morocco and Pakistan. In Nigeria, women expressed significantly more support for suicide terrorism than men. Although these views, especially compared to previous research, are interesting, gender differences are distributed across the countries with both high and low overall justification of suicide terrorism and thus do not seem to explain the variation.

The same is true about age, where we perform pair-wise t-statistic and find no evidence of difference in justification of suicide bombing (see Appendix 2). In a few countries, younger population (40 and under) tends to support suicide terrorism more than the older population (over 40), but mostly the differences between the two age groups are small. One interesting example is Mali, where those aged 40 and under justify suicide terrorism to a larger extent, while e.g. in Bangladesh and Jordan, population over 40 is more supportive of suicide terrorism. Finally, we combined the two categories and looked at males under 40 as the group most often implied in suicide terrorism and terrorist acts in general. This does not shed any light on the differences in justification rates among the 16 countries either: only in Mali, a country with high overall justification rates, younger males expressed more radical views in support of suicide terrorism than older males (See Appendix 2).

These answers should be compared to earlier surveys in order to see if there are any changes in time. Unfortunately, the surveys are not available for the whole set of countries. Nevertheless, we looked at the PEW surveys with the same question between 2002 and 2007 on the countries on which data are available. We found that in the nine countries where the same question was asked in 2002 and 2007 , there is a decrease in support for suicide terrorism. There are no previous results for Mali. However, Indonesia and Pakistan show a noticeable decrease of support between 2002 and 2007: in Indonesia from 5 to 3\% and in Pakistan from 19 to 4\% among those who say that suicide terrorism is often justified. In Egypt, the data are not available for 2002, but there is a substantial decrease from spring 2006 to spring 2007 from 8 to $2 \%$ among those who say that suicide terrorism is often justified. 


\section{Statistics}

This section describes the statistical analysis of the relationship, first, between the justification of suicide terrorism and unfavorable opinions about the nine regional powers and, second, between the two dimensions of public opinion and the occurrence of terrorism.

Figure 2 shows no obvious correlation between justification of suicide attacks and unfavorable opinion of the nine regional powers. We conducted the Spearman test of independence between these two variables and found a $19 \%{ }^{13}$ probability that justification and unfavorable opinion are independent. We looked at the subgroup of countries $\mathrm{Y}$ about which the opinions in countries $\mathrm{X}$ were most unfavorable (including the European Union and the United States) and found no correlation between unfavorable opinion and justification of suicide attacks in countries X. We also normalized the unfavorable opinion about the target countries to get a comparative number across pairs; as benchmark we chose Japan since a question about Japan was asked in all the source countries and, on average, Japan is seen in neutral terms. We found no correlation with the justification of suicide bombings (Figure 3). On the basis of these analyses we conclude that the justification of suicide terrorism and unfavorable opinion in countries $\mathrm{X}$ towards countries $\mathrm{Y}$ are independent.

As the next step, we examined whether there is a relationship between the two dimensions of public opinion and the occurrence of international terrorism. We measured the occurrence of terrorism by the number of terrorist incidents originating from countries $\mathrm{X}$ (source countries) and directed against countries Y (target countries) between 2004 and 2008. In our sample, the average number of attacks per country in this period was 7.15. The highest number of terrorist incidents originated from Nigeria, ${ }^{14}$ which had in total 32 attacks in this period. No attacks were recorded from Kuwait, Malaysia, Morocco, Senegal and Tanzania. The average number (standard deviation) of terrorist incidents per pair of countries is 1 (2.92), while the maximum is 23 (the Nigeria - E.U. pair) and the minimum is no attacks for $73 \%$ of the total 120 -pair sample.

\footnotetext{
${ }^{13}$ When we include the Pakistan - India cell the Prob $>|t|=0.2889$.

${ }^{14}$ Excluding the attacks from Pakistan against India, i.e. 310 incidents.
} 
The bivariate correlation between the number of attacks from country $X$ towards country $Y$ and the justification of suicide attacks is 0.20 ( $\mathrm{p}$ value is $<0.05$ ), and the bivariate correlation between the number of attacks from country $\mathrm{X}$ against country $\mathrm{Y}$ and the unfavorable opinion in country $\mathrm{X}$ towards country $\mathrm{Y}$ is $0.14(\mathrm{p}$ is $=0.11)$.

The dependant variable takes values from 0 to $23^{15}$ and the value zero represents almost $73 \%$ of the total 120 observations, therefore, we tested whether the zero-inflated negative binomial model provides a fit (Krueger and Malečková 2009). We performed the Vuong test and found that negative binomial model is favored at the $10 \%$ significance level.

In Table 5 we use a negative binomial model similar to Krueger and Malečková (2009) to estimate the relationship between justification of suicide attacks and unfavorable opinion toward target countries on the one hand and the occurrence of terrorism on the other. Assuming it is not the case of reverse causality, we find that there is a positive relationship between justification of suicide bombing in country $\mathrm{X}$ and the number of attacks originating from that country. The increase of justification by one standard deviation corresponds to the increase of the number of attacks by $167 \%$. We obtain similar results for the relationship between unfavorable opinion towards target countries and the occurrence of terrorism. The increase of unfavorable opinion towards a target country by one standard deviation corresponds to a $65 \%$ increase in the number of attacks originating from the source country.

Next, we control for both measures of public opinion at the same time and then introduce the interaction term between the two variables in order to explore whether the effect of justification of suicide bombing on the occurrence of terrorism varies with the level of opinion and vice versa.

We estimate the following models:

(1) $E\left(y_{1} \mid x\right)=\exp \left(\alpha+\beta_{1} x_{1}+\beta_{2} x_{2}+\beta_{n} X_{n}+\varepsilon\right)$

(2) $E\left(y_{2} \mid x\right)=\exp \left(\alpha+\beta_{1} x_{1}+\beta_{2} x_{2}+\beta_{3}\left(x_{1} \cdot x_{2}\right)+\beta_{n} X_{n}+\eta\right)$

\footnotetext{
${ }^{15}$ The fact that the values of dependant variable range from 0 to 23 per pair raises problems of overdispersion and the test for overdispersion in our sample shows that it is significant $\mathrm{V}(\mathrm{y} \mid \mathrm{x})=\mathrm{E}(\mathrm{y} \mid \mathrm{x})+\mathrm{a}^{*}\left\{\mathrm{E}(\mathrm{y} \mid \mathrm{x})^{\wedge} 2\right\}$.
} 
where the (pair-specific) dependent variable $y$ is the number of attacks originating from country $\mathrm{X}$ towards country Y. $x_{1}$ is justification of suicide bombing among citizens of country X. $x_{2}$ (also pairspecific) represents unfavorable opinion in country X towards country Y. In Model (2) we add the interaction term $\left(x_{1} \cdot x_{2}\right)$, which represents country $\mathrm{X}$ with both justification of suicide bombing and unfavorable opinion towards country $\mathrm{Y}$ (also this variable is pair-specific). $X_{n}$ is a vector of other control variables that we use in our model, based on the choice of independent variables included in previous studies (GDP per capita of target and source countries; percentage of Muslim population in the country; population sizes of source and target countries; Civil Liberties in both group of countries and distance between the source and target country's capitals).

Our analysis confirms the findings of earlier studies (Krueger and Malečková 2009; Krueger and Laitin 2008; Derin-Güre 2009) according to which the increase of distance between the source and target country of terrorist incidents decreases the number of attacks. The size of a country's population increases the likelihood of terrorist incidents, i.e. the bigger population of a country, the more attacks it will produce. The likelihood of terrorist attacks increases with the level of civil liberties in the target country. Once we control for civil liberties in the target country, we find a lack of evidence that the richer countries are targets of international terrorism. We do not find evidence that a higher percentage of Muslims in a country affects the number of attacks originating from that country. We also test for the concave relationship of the effect of GDP per capita of the source countries and find that neither the countries with the lowest nor those with the highest GDP per capita in our sample engage in terrorism.

We find a strong correlation between public opinion (justification of suicide bombing and unfavorable opinion in countries $\mathrm{X}$ towards countries $\mathrm{Y}$ ) and the occurrence of terrorism. However, our results suggest that in order for terrorism to occur both dimensions of public opinion need to be high.

[Fig. 4]

Assuming that our results are not a statistical artifact, we find that by increasing the justification of suicide bombing by one standard deviation at the lowest level of unfavorable opinion will increase the number of attacks by $28.51 \%$; increasing justification of suicide bombing by one standard deviation at the highest level of unfavorable opinion in country $\mathrm{X}$ towards country $\mathrm{Y}$ will increase the number of 
attacks by $266.6 \%$.

[Fig. 5]

Similarly, we find that increasing unfavorable opinion in country $\mathrm{X}$ towards country $\mathrm{Y}$ by one standard deviation at low levels of justification will increase the number of attacks by $14 \%$. Increasing unfavorable opinion by one standard deviation at the high levels of justification of suicide bombing will result in an increase of the number of attacks by $196 \%$.

Our analysis suggests that for the occurrence of terrorism both dimensions of public opinion need to be present and a high justification rate of suicide bombing in a country will not result in a high number of attacks originating from that country if the rate of unfavorable opinions towards the target country is low.

This finding allows two different interpretations: while it is important that in country $\mathrm{X}$ there are people who justify suicide terrorism and those who have unfavorable opinion of the target country, these can be two separate groups, or, alternatively, what is significant is the share of people who both justify suicide terrorism and, at the same time, have unfavorable opinion of country $\mathrm{Y}$.

In order to find out which of the two interpretations is correct, we used the PEW Survey's individual level data to explore the group of respondents in country X who both held unfavorable views of country $\mathrm{Y}$ and justified suicide bombings. We constructed a variable "Justify \& Unfavorable Opinion", which represents the share of people in country X who at the same time ("often" and "sometimes") justify suicide bombing and have ("somewhat" and "very") unfavorable opinion towards the target country. Table 7 shows the relationship between this group of respondents and the occurrence of terrorism. ${ }^{16} \mathrm{We}$ find a sizable and positive relationship between the group of people in country $\mathrm{X}$ who at the same time justify suicide bombing as a means of struggle and have unfavorable opinion of country $\mathrm{Y}$ and terrorist attacks originating from country $\mathrm{X}$ against country $\mathrm{Y} .{ }^{17}$

\footnotetext{
${ }^{16}$ The results do not change if we cluster by source country.
} 
We then looked at the different combinations, i.e. the group of people who justify suicide terrorism and have unfavorable opinion towards the target country; those who justify and have favorable opinion towards the target country; those who do not believe suicide terrorism is justified and have unfavorable opinion towards the target country; and finally those who do not justify suicide terrorism and have favorable opinion towards the target country. We considered the share of people who do not justify suicide terrorism and have favorable opinion towards the target country as a base and included the other three variables in the regression. Table 8 shows the results, which confirm our finding about the robust positive relationship between the share of people who both justify suicide terrorism and have unfavorable opinion towards the target country and the number of terrorist attacks from the source country against the target country. We find that the increase of this critical share of people by one standard deviation increases the attacks by $266 \%{ }^{18}$

\section{Robustness Checks}

In order to check for robustness we test different statistical models of the effect of public opinion (justification of suicide attacks and unfavorable opinion of target countries) on the occurrence of terrorism. First, we control for the regions - Asia, Africa and the Middle East - and find no difference in our findings. We also control for the U.S. and the E.U. as the most common targets in our data set. We find that once we control for the U.S. and the E.U., civil liberties do not play a role in the prediction of targets of attacks (Table 4). We also check whether the fact that a country has a large dominant neighbor has any influence on the occurrence of terrorism. We construct a variable Big Neighbors ${ }^{19}$ and find no significant effect. Also considering whether a country where terrorism originates is a former colony (Derin-Güre 2009) shows no significant effect; in addition, the coefficient of the interaction term increases.

To obtain our results, we relied on the negative binomial estimation technique and relaxed the assumption that the variance is equal to the mean. However, we get similar results when we apply the Poisson estimation with robust standard errors; in addition, the significance level of the interaction term becomes stronger below 0.05 level. Furthermore, we compare different estimations in Table 5 and get

\footnotetext{
${ }^{18}$ The results remain the same if we cluster by source country.

${ }^{19}$ (Population X/Population Y)*Dummy for the same region.
} 
the same results. When we include the Pakistan - India cell, the coefficient (standard error) of justification of suicide bombing is 5.328 (1.539) below 0.01 significance level and the coefficient of unfavorable opinion is 1.90 (0.976) below 0.1 significance level in Model (1). In Model (2) the coefficient (standard error) of the interaction term is $7.70(4.648)(\mathrm{p}<0.10)$. Similarly to earlier studies (Krueger and Malečková 2009; Derin-Güre 2009) we also use binary outcome as dependent variable and test our models by using logit estimation instead of number of attacks. We assign 0 if attacks did not happen and 1 if attacks occurred between the pairs of countries. We find that the coefficient (standard error $^{20}$ ) of the interaction term in Model (2) is 16.83 (9.14) and $\mathrm{p}>|\mathrm{z}|=0.06$.

\section{Conclusions}

Our research confirms the relevance of public opinion for terrorism. It also suggests that public opinion should be explored separately across its different dimensions. We focused on opinions towards regional powers and justification of suicide terrorism. Based on research on Anti-Americanism, it would be useful to explore the relationship between further dimensions of public opinion, such as attitudes towards values (democracy) and attitudes toward more specific expressions of foreign policy (e.g. in the Middle East), and their effect on the occurrence of terrorism. Confirming earlier studies, our results show a large variation on both dimensions across the 16 countries. From the perspective of security policy, this means that there is no single easy remedy applicable across countries.

Our study shows that justification of suicide terrorism and unfavorable opinions of regional powers are truly distinct dimensions of public opinion, with separate sources of variation. The sources of justification of suicide terrorism (or terrorism more generally) and unfavorable opinions of regional powers are not well known. Earlier studies of public opinion (Tessler and Robbins 2007; Krueger and Malečková 2009; Chiozza 2006) have suggested that the aspect of attitudes to a country relevant for the support of terrorism and/or occurrence of terrorism concern foreign policy of that country. Our results are in line with these findings. However, more research is necessary on the sources of justification of terrorism. 
We found a positive relationship between justification of suicide bombing in a country and the number of incidents originating from that country as well as between unfavorable opinion in the source country towards the target country and terrorist attacks from the source country against the target country. This confirms the finding of the previous study with Alan Krueger on the positive relationship between public opinion and the occurrence of terrorism. However, our study suggests that what matters is that both dimensions of public opinion are present: the intersection between justification of suicide terrorism and unfavorable opinion of regional powers is correlated with the occurrence of terrorism. The effect of justification of suicide terrorism on the occurrence of terrorism is proportional to unfavorable opinion (and conversely, the effect of unfavorable opinion is proportional to justification of suicide terrorism). This means that the countries where justification of suicide terrorism is high will not necessarily be the source of a higher number of attacks if unfavorable opinions of the target country in the source country are low.

In addition, we find that it is not sufficient for the unfavorable attitudes towards regional powers and justification of suicide bombing to be spread among various groups in a country. It is important that the same group of people in a country both holds negative views of a potential enemy (regional power) and believes that suicide terrorism is a justifiable means of struggle. This finding, and the particular share of the population who hold these negative views, deserve more attention in future research in order to find out more about how these attitudes translate into action. Is it the material support and legitimization that effect the intensity of terrorist incidents, or does this group present the actual pool of potential recruits?

If our findings hold they have relevant implications for security policy. Our main finding suggests that it is useful to watch for cases where both unfavorable opinion of a country and justification of (suicide) terrorism are high as these may be warning signals that terrorism originating from the former country and targeted against the latter country may rise. Moreover, if justification of suicide terrorism in a certain community is high and difficult to affect, efforts could focus on influencing opinion about the country or countries that are the targets of terrorist attacks originating from the society in question. The improvement of the opinion of these countries should lead to a decrease in the number of attacks. And conversely, when suicide terrorism and other forms of extreme violence is successfully discredited (Craigin and Gerwehr 2005) as a means of solving grievances, the number of attacks against a country may decrease even if opinions of the country remain negative. 


\section{References}

Alonso, R. (2006). Individual Motivations for Joining Terrorist Organizations: A Comparative Qualitative Study on Members of ETA and IRA, in J. Victoroff, Tangled Roots: Social and Psychological Factors in the Genesis of Terrorism, Amsterdam (IOS Press), 187-202.

Berrebi, C. and Klor, E. (2006). On Terrorism and Electoral Outcomes: Theory and Evidence from the Israeli-Palestinian Conflict. Journal of Conflict Resolution 50(6), 899-925.

Chiozza, G. (2006). Disaggregating Anti-Americanism: An Analysis of Individual Attitudes toward the United States in P. J. Katzenstein, R. O. Keohane (Eds.), Anti-Americanisms in World Politics, Ithaca (Cornell Univ. Press), 93-128.

Craigin, K. and Gerwehr, S. (2005). Dissuading terror : strategic influence and the struggle against terrorism. Santa Monica (RAND Corp.).

Derin-Güre, P. (2009). Does Terrorism Have Economic Roots? Boston University - Department of Economics - Working Papers Series. Boston University - Department of Economics. wp2009-001.

Fair, Ch. C. and Shephered, B. (2006). Who Supports Terrorism? Evidence from Fourteen Muslim Countries. Studies in Conflict \& Terrorism 29: 51-54.

Gurr, T.R. (1998). Terrorism in democracies: Its social and political bases, in W. Reich (ed.), Origins of Terrorism. Psychologies, Ideologies, Theologies, States of Mind, Washington (Woodrow Wilson Center Press), 86-102.

Hassan, N. (2006). Suicide Terrorism, in L. Richardson (Ed.), The Roots of Terrorism. New York (Routledge): 29-42.

Katzenstein, P.J. and Keohane, R.O. (2006). The Political Consequences of Anti-Americanism, in P. J. Katzenstein, R. O. Keohane (Eds.), Anti-Americanisms in World Politics, Ithaca (Cornell Univ. Press), 273-305.

Krueger, A.B. (2007). What Makes a Terrorist: Economics and the Roots of Terrorism. PrincetonOxford (Princeton University Press).

Krueger, A. and Laitin, D. (2008) Kto Kogo?: A Cross-Country Study of the Origins and Targets of Terrorism, in P. Keefer, N. Loayza, Eds. Terrorism, Economic Development, and Political Openness, Cambridge (Cambridge Univ. Press): 148-173.

Krueger, A. and Malečková, J. (2009). Attitudes and Action: Public Opinion and the Occurrence of International Terrorism", Science: $1534-1536$ 
Malečková, J. (2006). Terrorists and the Societies from Which They Come, in J. Victoroff, Tangled Roots: Social and Psychological Factors in the Genesis of Terrorism, Amsterdam (IOS Press), 147-161. Merrari, A. (2005). Social, Organizational and Psychological Factors in Suicide Terrorism, in T. Bjørgo, Root Causes of Terrorism: Myths, Reality and Ways Forward. London and New York (Routledge), 70-86.

Pinar 2008

Tessler, M. and Robbins, M.D.H. (2007). What Leads Some Ordinary Arab Men and Women to Approve of Terrorist Acts Against the United States? Journal of Conflict Resolution 51: 305-328.

Victoroff, J., Qouta, S., Celinska, B., Abu-Safieh, R., Adelman, J. and Stern, N. (2006). Sympathy for Terrorism: Possible Interaction Between Social, Emotional, and Neuroendocrine Risk Factors, in J. Victoroff, Tangled Roots: Social and Psychological Factors in the Genesis of Terrorism, Amsterdam (IOS Press), 227-234.

\section{Data}

- The PEW Global Attitudes Project, Rising Environmental Concern in 47 - Nation Survey, Global Unease with Major World Powers. www.pewglobal.org/datasets/

- Data on Terrorist Incidents are available at National Counterterrorism Center, The Worldwide Incidents Tracking System. www.wits.nctc.gov

- GDP per capita is calculated average from 2002 to 2006. World Bank datasets, WDI World Development Indicators. www.worldbank.org

- Population in Millions. World Bank datasets, WDI World Development Indicators. www.worldbank.org

- Civil Rights. Freedom House, 1 to 7 inverse scale. www.freedomhouse.org

- Muslim percentage in country. CIA The World Factbook. www.cia.gov 


\section{Appendix 1.}

Table 1. Summary Statistics of Dependent and Independent Variables

\begin{tabular}{|c|c|c|c|c|c|}
\hline Variable & Obs & Mean & Std. Dev. & Min & Max \\
\hline \multicolumn{6}{|c|}{ Dependent Variable (number of attacks from $X$ against $Y$ ) } \\
\hline Attacks & 120 & 1.000 & 2.925 & 0 & 23 \\
\hline \multicolumn{6}{|c|}{ Public Opinion in Source Country X } \\
\hline Justification & 120 & 0.233 & 0.158 & 0.080 & 0.7 \\
\hline Opinion & 120 & 0.319 & 0.195 & 0.020 & 0.86 \\
\hline Justification\& & & & & & \\
\hline Opinion & 120 & 0.080 & 0.092 & 0.002 & 0.602 \\
\hline Justify \& Unf.Op. & 120 & 0.087 & 0.096 & 0.002 & 0.638 \\
\hline Justify \& Fav. Op. & 120 & 0.127 & 0.096 & 0.009 & 0.469 \\
\hline NoJust. \& Unf.Op. & 120 & 0.216 & 0.147 & 0.017 & 0.643 \\
\hline \multicolumn{6}{|l|}{ Source Country X } \\
\hline Population X & 120 & 7.499 & 0.624 & 6.425 & 8.353 \\
\hline Civil Liberties X & 120 & 3.900 & 0.824 & 2.000 & 5 \\
\hline GDP per capita $X$ & 120 & 3.086 & 0.552 & 2.148 & 4.310 \\
\hline GDPper capita^2X & 120 & 9.826 & 3.566 & 4.614 & 18.575 \\
\hline Muslim Religion & 120 & 0.779 & 0.203 & 0.328 & 0.99 \\
\hline ExColonies & 120 & 0.692 & 0.464 & 0 & 1 \\
\hline Big Neighbors & 120 & 0.282 & 0.482 & 0 & 1.23 \\
\hline \multicolumn{6}{|l|}{ Target Country Y } \\
\hline Civil Liberties of $Y$ & 120 & 3.842 & 2.150 & 1 & 6 \\
\hline GDP per capita $Y$ & 120 & 3.849 & 0.717 & 2.280 & 5.952 \\
\hline Distance $X-Y$ & 120 & 3.707 & 0.328 & 2.603 & 4.213 \\
\hline Population Y & 120 & 8.139 & 0.520 & 7.383 & 9.120 \\
\hline
\end{tabular}


Table 2. Overview of Source Countries by Dimensions of Public Opinion

\begin{tabular}{|c|c|c|c|c|c|}
\hline Country X & Obs & Mean & Stan. Dev. & Min & Max \\
\hline $\begin{array}{l}\text { Justification of } \\
\text { Suicide } \\
\text { Bombing }\end{array}$ & 16 & 0.232 & 0.158 & 0.08 & 0.7 \\
\hline \multicolumn{6}{|c|}{ Unfavorable Opinion of $X$ towards $Y$ Across Pairs of Countries } \\
\hline Country $X$ & Obs. & Mean & Stan. Dev. & Min & Max \\
\hline Bangladesh & 9 & 0.224 & 0.134 & 0.06 & 0.41 \\
\hline Egypt & 7 & 0.429 & 0.212 & 0.08 & 0.78 \\
\hline Ethiopia & 6 & 0.262 & 0.193 & 0.08 & 0.59 \\
\hline Indonesia & 9 & 0.246 & 0.189 & 0.08 & 0.66 \\
\hline Jordan & 8 & 0.457 & 0.245 & 0.1 & 0.78 \\
\hline Kuwait & 8 & 0.27 & 0.132 & 0.14 & 0.46 \\
\hline Lebanon & 8 & 0.429 & 0.155 & 0.17 & 0.64 \\
\hline Malaysia & 9 & 0.254 & 0.177 & 0.1 & 0.69 \\
\hline Mali & 6 & 0.207 & 0.138 & 0.07 & 0.42 \\
\hline Morocco & 8 & 0.264 & 0.134 & 0.15 & 0.56 \\
\hline Nigeria & 6 & 0.258 & 0.115 & 0.16 & 0.47 \\
\hline Tanzania & 6 & 0.245 & 0.19 & 0.08 & 0.56 \\
\hline Turkey & 8 & 0.52 & 0.16 & 0.37 & 0.83 \\
\hline Palestine & 8 & 0.503 & 0.173 & 0.33 & 0.86 \\
\hline Pakistan & 9 & 0.306 & 0.275 & 0.02 & 0.8 \\
\hline Senegal & 6 & 0.233 & 0.146 & 0.09 & 0.43 \\
\hline Opinion & 121 & 0.322 & 0.199 & 0.02 & 0.86 \\
\hline
\end{tabular}


Table 3. Unfavorable Opinion towards Target Countries

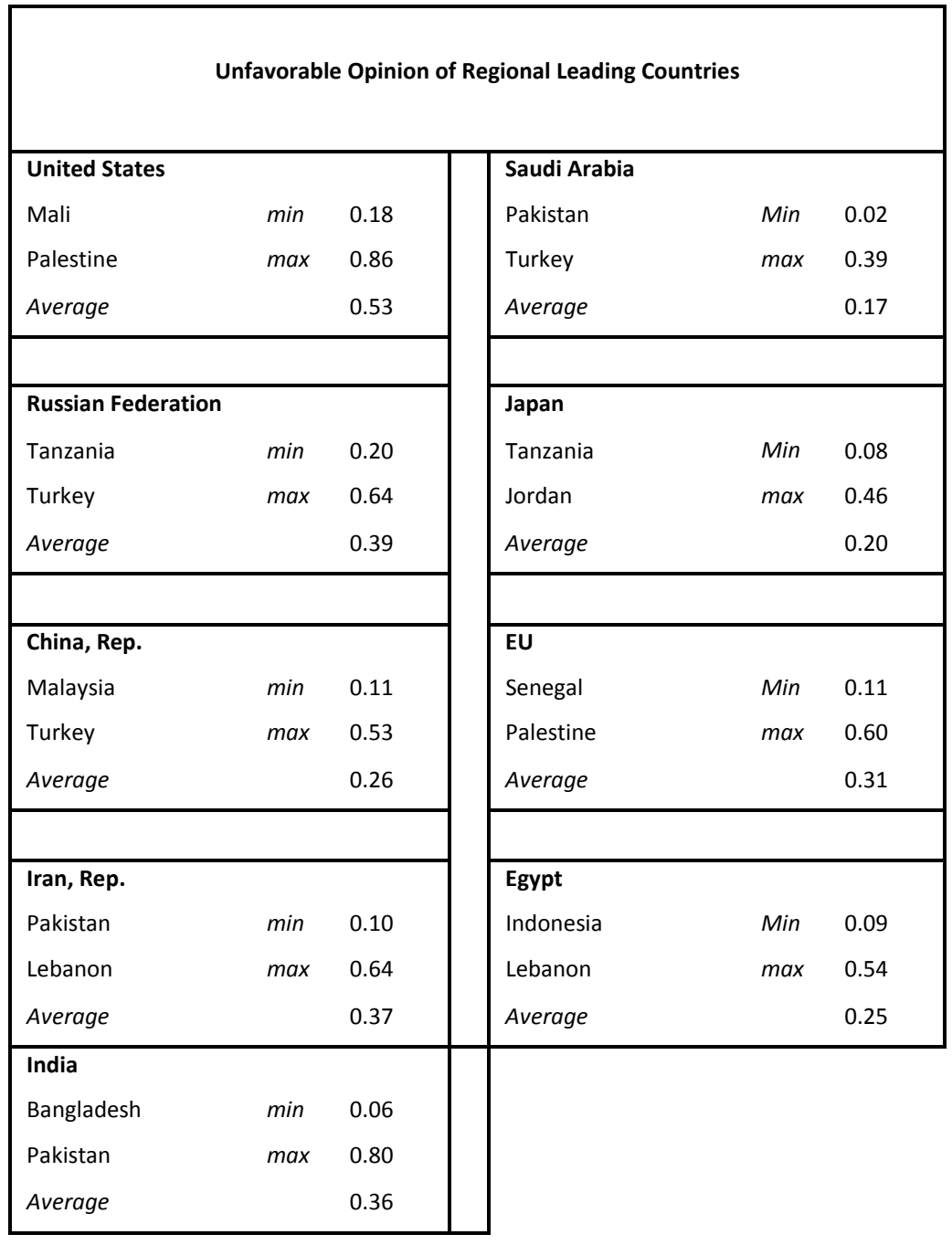


Table 4. Lowest, Highest and Average Unfavorable Opinion over Pairs of Countries

Sample percentage of unfavorable opinion towards regional leading countries. The least unfavorable, the most unfavorable and average per source country.

\begin{tabular}{|c|c|c|c|}
\hline Bangladesh/India & 0.06 & Mali/China & 0.07 \\
\hline Bangladesh/US & 0.41 & Mali/Iran & 0.42 \\
\hline Average & 0.22 & Average & 0.21 \\
\hline Egypt /Saudi Arabia & 0.08 & Morocco /Saudi Arabia low & 0.15 \\
\hline Egypt/US & 0.78 & Morocco /US & 0.56 \\
\hline Average & 0.43 & Average & 0.26 \\
\hline Ethiopia/Japan & 0.08 & Nigeria/Japan & 0.16 \\
\hline Ethiopia/Iran & 0.59 & Nigeria/Iran & 0.47 \\
\hline Average & 0.26 & Average & 0.26 \\
\hline Indonesia/Saudi Arabia low & 0.08 & Pakistan/Saudi Arabia low & 0.02 \\
\hline Indonesia/US & 0.66 & Pakistan/US & 0.68 \\
\hline Average & 0.25 & Average & 0.24 \\
\hline Jordan/Saudi Arabia low & 0.10 & Senegal/Japan & 0.09 \\
\hline Jordan/US & 0.78 & Senegal/Iran & 0.43 \\
\hline Average & 0.46 & Average & 0.23 \\
\hline Kuwait/Japan & 0.14 & Tanzania/Japan & 0.08 \\
\hline Kuwait/US & 0.46 & Tanzania/Iran & 0.56 \\
\hline Average & 0.27 & Average & 0.25 \\
\hline Lebanon/Saudi Arabia low & 0.17 & Turkey/Egypt & 0.37 \\
\hline Lebanon/Iran & 0.64 & Turkey/US & 0.83 \\
\hline Average & 0.43 & Average & 0.52 \\
\hline Malaysia/Japan & 0.10 & Palestine/Saudi Arabia low & 0.33 \\
\hline Malaysia/US & 0.69 & Palestine/US & 0.86 \\
\hline Average & 0.25 & Average & 0.5 \\
\hline
\end{tabular}


Table 5. Negative Binomial Model of Public Opinion and Terrorist Incidents between Pairs of Countries (Clustered by Countries X)

\begin{tabular}{|c|c|c|c|c|c|c|c|c|}
\hline VARIABLES & $\begin{array}{c}(1) \\
\text { Attacks } \\
\end{array}$ & $\begin{array}{c}(2) \\
\text { Attacks } \\
\end{array}$ & $\begin{array}{c}(3) \\
\text { Attacks }\end{array}$ & $\begin{array}{c}(4) \\
\text { Attacks }\end{array}$ & $\begin{array}{c}(5) \\
\text { Attacks }\end{array}$ & $\begin{array}{c}(6) \\
\text { Attacks } \\
\end{array}$ & $\begin{array}{c}(7) \\
\text { Attacks }\end{array}$ & $\begin{array}{c}(8) \\
\text { Attacks } \\
\end{array}$ \\
\hline $\begin{array}{l}\text { Justification } \\
\text { Opinion } \\
\text { Justification *Opinion }\end{array}$ & $\begin{array}{c}6.136^{* * *} \\
(1.188)\end{array}$ & $\begin{array}{c}3.146^{* *} \\
(1.279)\end{array}$ & $\begin{array}{c}5.355^{* * *} * \\
(1.176) \\
1.797 * * \\
(0.905)\end{array}$ & $\begin{array}{l}1.425 \\
(2.623) \\
0.0681 \\
(0.967) \\
7.873^{*} \\
(4.080)\end{array}$ & $\begin{array}{l}0.125 \\
(2.571) \\
-0.294 \\
(1.007) \\
10.40^{* *} \\
(4.326)\end{array}$ & $\begin{array}{l}1.317 \\
(2.639) \\
-0.134 \\
(1.067) \\
8.117^{* *} \\
(4.107)\end{array}$ & $\begin{array}{l}2.531 \\
(2.496) \\
-0.878 \\
(1.074) \\
8.481^{* *} \\
(3.965)\end{array}$ & $\begin{array}{c}2.004 \\
(2.451) \\
-0.0894 \\
(0.666) \\
7.241 * * \\
(3.116)\end{array}$ \\
\hline Distance $X$ to $Y$ & $-3.142 * * *$ & $-4.341 * * *$ & $-3.386 * * *$ & $-3.638 * * *$ & $-3.570 * * *$ & $-3.832^{* * *}$ & $-3.145 * * *$ & $-2.887 * * *$ \\
\hline Population X & $\begin{array}{c}3.050^{* * *} * \\
(0.419)\end{array}$ & $\begin{array}{c}2.040 * * * \\
(0.454)\end{array}$ & $\begin{array}{c}3.040 * * * \\
(0.427)\end{array}$ & $\begin{array}{c}3.316^{* * *} \\
(0.617)\end{array}$ & $\begin{array}{c}3.238^{* * *} \\
(0.607)\end{array}$ & $\begin{array}{c}3.334 * * * \\
(0.608)\end{array}$ & $\begin{array}{c}3.466^{* * *} * \\
(0.587)\end{array}$ & $\begin{array}{c}3.363^{* * * *} \\
(0.693)\end{array}$ \\
\hline Population $Y$ & $\begin{array}{c}1.025 * * * \\
(0.286)\end{array}$ & $\begin{array}{c}0.924 * * \\
(0.386)\end{array}$ & $\begin{array}{c}0.867 * * * \\
(0.328)\end{array}$ & $\begin{array}{c}0.875 * * * \\
(0.338)\end{array}$ & $\begin{array}{c}0.890 * * \\
(0.366)\end{array}$ & $\begin{array}{c}0.978 * * \\
(0.425)\end{array}$ & $\begin{array}{c}0.905 * * * \\
(0.302)\end{array}$ & $\begin{array}{c}1.074 * * * \\
(0.244)\end{array}$ \\
\hline Civil Liberties $X$ & $\begin{array}{c}0.349^{* *} \\
(0.167)\end{array}$ & $\begin{array}{c}0.152 \\
(0.281)\end{array}$ & $\begin{array}{c}0.256 \\
(0.219)\end{array}$ & $\begin{array}{c}0.196 \\
(0.267)\end{array}$ & $\begin{array}{c}0.324 \\
(0.264)\end{array}$ & $\begin{array}{c}0.190 \\
(0.270)\end{array}$ & $\begin{array}{c}0.149 \\
(0.306)\end{array}$ & $\begin{array}{c}0.293 \\
(0.278)\end{array}$ \\
\hline$G D P$ per capita $X$ & $\begin{array}{c}3.531 \\
(5.520)\end{array}$ & $\begin{array}{c}13.13 * * * \\
(4.784)\end{array}$ & $\begin{array}{c}2.908 \\
(5.164)\end{array}$ & $\begin{array}{c}2.851 \\
(5.078)\end{array}$ & $\begin{array}{c}4.739 \\
(5.019)\end{array}$ & $\begin{array}{c}3.007 \\
(5.083)\end{array}$ & $\begin{array}{c}6.375 \\
(6.442)\end{array}$ & $\begin{array}{c}1.865 \\
(5.286)\end{array}$ \\
\hline GDP per capita $X 2$ & $\begin{array}{l}-0.399 \\
(0.848)\end{array}$ & $\begin{array}{c}-2.159 * * * \\
(0.722)\end{array}$ & $\begin{array}{l}-0.370 \\
(0.787)\end{array}$ & $\begin{array}{l}-0.330 \\
(0.757)\end{array}$ & $\begin{array}{l}-0.563 \\
(0.735)\end{array}$ & $\begin{array}{l}-0.349 \\
(0.760)\end{array}$ & $\begin{array}{c}-0.958 \\
(1.040)\end{array}$ & $\begin{array}{l}-0.140 \\
(0.804)\end{array}$ \\
\hline Portion Muslim & $\begin{array}{c}0.996 \\
(1.626)\end{array}$ & $\begin{array}{l}-2.294 \\
(1.466)\end{array}$ & $\begin{array}{c}0.320 \\
(1.685)\end{array}$ & $\begin{array}{c}-0.578 \\
(1.923)\end{array}$ & $\begin{array}{c}0.917 \\
(2.430)\end{array}$ & $\begin{array}{c}-0.555 \\
(1.909)\end{array}$ & $\begin{array}{c}0.114 \\
(1.957)\end{array}$ & $\begin{array}{c}-0.00523 \\
(1.921)\end{array}$ \\
\hline Civil Liberties $Y$ & $\begin{array}{c}-0.603 * * * \\
(0.143)\end{array}$ & $\begin{array}{c}-0.492 * * * \\
(0.141)\end{array}$ & $\begin{array}{c}-0.494 * * * \\
(0.153)\end{array}$ & $\begin{array}{c}-0.530^{* * *} \\
(0.158)\end{array}$ & $\begin{array}{c}-0.490^{* * *} \\
(0.169)\end{array}$ & $\begin{array}{c}-0.519 * * * \\
(0.156)\end{array}$ & $\begin{array}{c}-0.549 * * * \\
(0.165)\end{array}$ & $\begin{array}{c}-0.0266 \\
(0.230)\end{array}$ \\
\hline GDP per capita $Y$ & $\begin{array}{l}-0.0950 \\
(0.312)\end{array}$ & $\begin{array}{c}0.349 \\
(0.406)\end{array}$ & $\begin{array}{c}0.156 \\
(0.363)\end{array}$ & $\begin{array}{c}0.119 \\
(0.380)\end{array}$ & $\begin{array}{c}0.257 \\
(0.478)\end{array}$ & $\begin{array}{c}0.169 \\
(0.402)\end{array}$ & $\begin{array}{l}0.0755 \\
(0.375)\end{array}$ & $\begin{array}{c}0.488 \\
(0.372)\end{array}$ \\
\hline $\begin{array}{l}\text { Middle East } \\
\text { Asia }\end{array}$ & & & & & $\begin{array}{c}-1.387 \\
(1.317) \\
-1.262 \\
(1.159)\end{array}$ & & & \\
\hline Big Neighbors & & & & & & $\begin{array}{l}-0.230 \\
(0.400)\end{array}$ & & \\
\hline Former Colonies & & & & & & & $\begin{array}{c}-0.983 \\
(0.771)\end{array}$ & \\
\hline US & & & & & & & & $\begin{array}{l}1.513 * * \\
(0.731)\end{array}$ \\
\hline$E U$ & & & & & & & & $\begin{array}{c}2.335^{* * * *} \\
(0.800)\end{array}$ \\
\hline Constant & $\begin{array}{c}-28.87 * * * \\
(8.277)\end{array}$ & $\begin{array}{c}-26.71 * * * \\
(10.21)\end{array}$ & $\begin{array}{c}-25.89 * * * \\
(7.853)\end{array}$ & $\begin{array}{c}-25.36 * * * \\
(9.604)\end{array}$ & $\begin{array}{c}-29.78 * * * \\
(9.850)\end{array}$ & $\begin{array}{c}-26.00^{* * * *} \\
(9.455)\end{array}$ & $\begin{array}{c}-32.85^{* * * *} \\
(11.64)\end{array}$ & $\begin{array}{c}-33.74 * * * \\
(9.363)\end{array}$ \\
\hline$N$ & 120 & 120 & 120 & 120 & 120 & 120 & 120 & 120 \\
\hline
\end{tabular}


Table 6. Estimation Comparisons

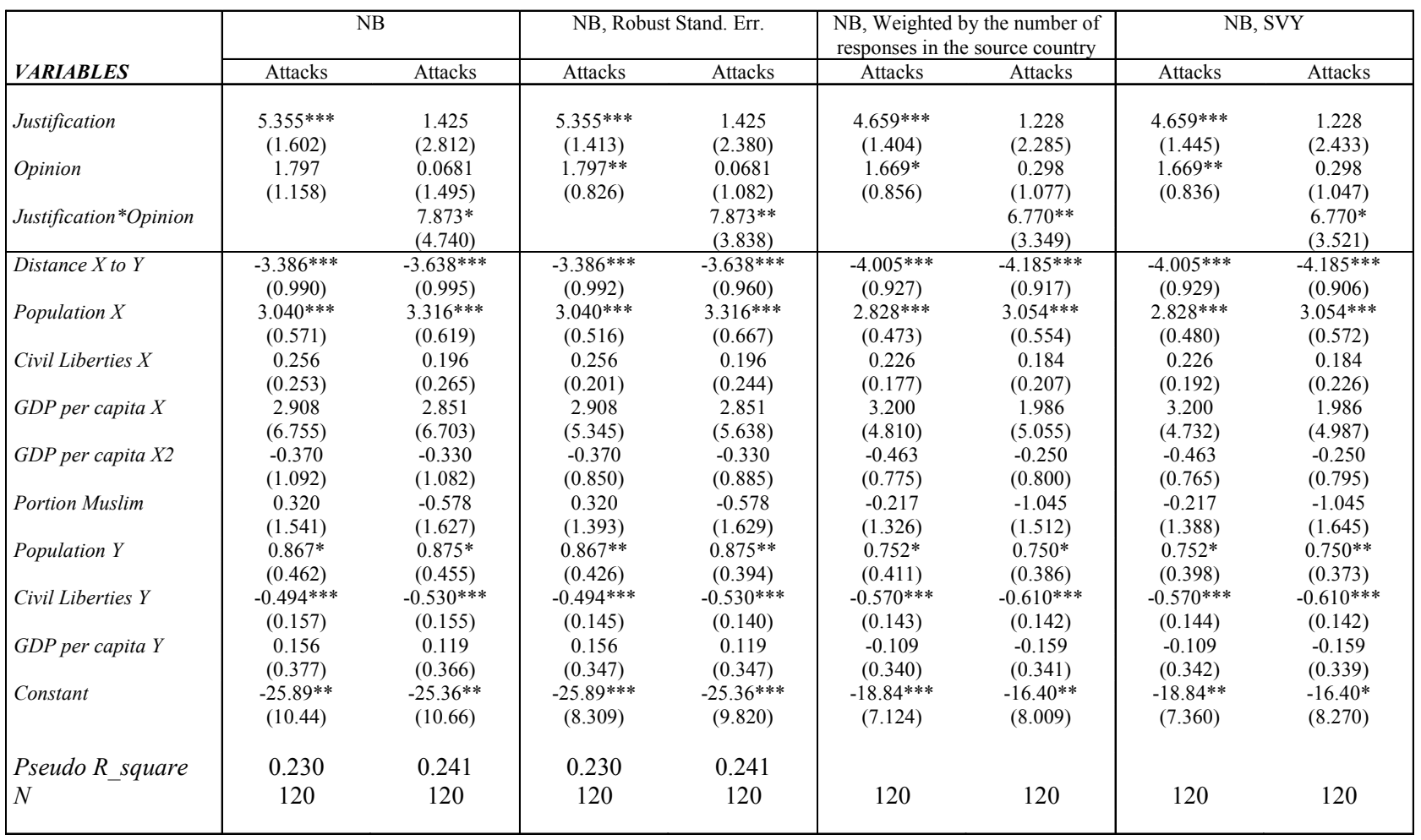


Table 7. Estimation Comparison

\begin{tabular}{|c|c|c|c|c|}
\hline VARIABLES & NB & NB, robust s.e & $\begin{array}{l}\mathrm{NB}, \text { Weighted } \\
\text { by number of } \\
\text { responses in the } \\
\text { source country }\end{array}$ & NB, SVY \\
\hline Justification & $\begin{array}{c}0.859 \\
(2.518)\end{array}$ & $\begin{array}{c}0.859 \\
(2.306)\end{array}$ & $\begin{array}{c}1.189 \\
(2.087)\end{array}$ & $\begin{array}{l}1.189 \\
(2.092)\end{array}$ \\
\hline Opinion & $\begin{array}{c}0.247 \\
(1.294)\end{array}$ & $\begin{array}{c}0.247 \\
(0.994)\end{array}$ & $\begin{array}{c}0.780 \\
(1.108)\end{array}$ & $\begin{array}{c}0.780 \\
(1.109)\end{array}$ \\
\hline Justify \& Unf. Opinion & $\begin{array}{c}9.094 * * \\
(4.098)\end{array}$ & $\begin{array}{l}9.094 * * \\
(4.152)\end{array}$ & $\begin{array}{l}6.621^{*} \\
(3.658)\end{array}$ & $\begin{array}{l}6.621 * \\
(3.660)\end{array}$ \\
\hline Distance $X-Y$ & $\begin{array}{c}-3.423 * * * \\
(0.958)\end{array}$ & $\begin{array}{c}-3.423 * * * \\
(0.917)\end{array}$ & $\begin{array}{c}-3.901 * * * \\
(0.879)\end{array}$ & $\begin{array}{c}-3.901 * * * \\
(0.880)\end{array}$ \\
\hline Population $X$ & $\begin{array}{c}3.303 * * * \\
(0.612)\end{array}$ & $\begin{array}{c}3.303 * * * \\
(0.687)\end{array}$ & $\begin{array}{c}2.981^{* * *} \\
(0.578)\end{array}$ & $\begin{array}{c}2.981 * * * \\
(0.579)\end{array}$ \\
\hline Civil Liberties $X$ & $\begin{array}{c}0.194 \\
(0.266)\end{array}$ & $\begin{array}{c}0.194 \\
(0.248)\end{array}$ & $\begin{array}{c}0.180 \\
(0.197)\end{array}$ & $\begin{array}{c}0.180 \\
(0.198)\end{array}$ \\
\hline GDP per capita $X$ & $\begin{array}{c}2.885 \\
(6.865)\end{array}$ & $\begin{array}{c}2.885 \\
(5.775)\end{array}$ & $\begin{array}{c}1.788 \\
(5.352)\end{array}$ & $\begin{array}{c}1.788 \\
(5.360)\end{array}$ \\
\hline GDP per capita $X 2$ & $\begin{array}{c}-0.378 \\
(1.113)\end{array}$ & $\begin{array}{l}-0.378 \\
(0.910)\end{array}$ & $\begin{array}{l}-0.260 \\
(0.850)\end{array}$ & $\begin{array}{l}-0.260 \\
(0.851)\end{array}$ \\
\hline Portion Muslim & $\begin{array}{l}0.0361 \\
(1.553)\end{array}$ & $\begin{array}{l}0.0361 \\
(1.576)\end{array}$ & $\begin{array}{l}-0.549 \\
(1.455)\end{array}$ & $\begin{array}{l}-0.549 \\
(1.457)\end{array}$ \\
\hline Population $Y$ & $\begin{array}{c}0.726 \\
(0.445)\end{array}$ & $\begin{array}{l}0.726^{*} \\
(0.394)\end{array}$ & $\begin{array}{c}0.579 \\
(0.410)\end{array}$ & $\begin{array}{c}0.579 \\
(0.409)\end{array}$ \\
\hline Civil Liberties $Y$ & $\begin{array}{c}-0.441 * * * \\
(0.149)\end{array}$ & $\begin{array}{c}-0.441 * * * \\
(0.140)\end{array}$ & $\begin{array}{c}-0.511 * * * \\
(0.132)\end{array}$ & $\begin{array}{c}-0.511 * * * \\
(0.132)\end{array}$ \\
\hline GDP per capita $Y$ & $\begin{array}{c}0.225 \\
(0.358)\end{array}$ & $\begin{array}{c}0.225 \\
(0.344)\end{array}$ & $\begin{array}{r}-0.0604 \\
(0.318)\end{array}$ & $\begin{array}{l}-0.0604 \\
(0.318)\end{array}$ \\
\hline Constant & $\begin{array}{c}-25.86^{* *} \\
(10.89)\end{array}$ & $\begin{array}{c}-25.86^{* *} \\
(10.48)\end{array}$ & $\begin{array}{l}-16.14^{*} \\
(8.304)\end{array}$ & $\begin{array}{c}-16.14 * \\
(8.323)\end{array}$ \\
\hline Pseudo $R$ square & 0.25 & 0.25 & & \\
\hline$N$ & 120 & 120 & 120 & 120 \\
\hline
\end{tabular}


Table 8. Negative Binomial Estimation of Shares of Population by Public Opinion And Number of Attacks

\begin{tabular}{|c|c|c|c|c|}
\hline & NB & $\begin{array}{c}\text { NB, robust } \\
\text { st.e }\end{array}$ & $\begin{array}{c}\text { NB, } \\
\text { Weighted }\end{array}$ & NB, SVY \\
\hline VARIABLES & Attacks & Attacks & Attacks & Attacks \\
\hline Justify\&Unf.Opinion & $\begin{array}{c}10.25 * * * \\
(2.242)\end{array}$ & $\begin{array}{c}10.25 * * * \\
(2.180)\end{array}$ & $\begin{array}{c}8.665 * * * \\
(1.957)\end{array}$ & $\begin{array}{c}8.665^{* * * *} \\
(1.899)\end{array}$ \\
\hline Justify\& Fav.Op. & $\begin{array}{c}1.696 \\
(2.952)\end{array}$ & $\begin{array}{c}1.696 \\
(2.834)\end{array}$ & $\begin{array}{c}1.383 \\
(2.611)\end{array}$ & $\begin{array}{c}1.383 \\
(2.561)\end{array}$ \\
\hline NoJus.\&Unf.Opinion & $\begin{array}{c}1.018 \\
(1.438)\end{array}$ & $\begin{array}{c}1.018 \\
(1.279)\end{array}$ & $\begin{array}{c}0.972 \\
(1.261)\end{array}$ & $\begin{array}{c}0.972 \\
(1.274)\end{array}$ \\
\hline Distance $X-Y$ & $\begin{array}{c}-3.462 * * * \\
(0.978)\end{array}$ & $\begin{array}{c}-3.462 * * * \\
(0.960)\end{array}$ & $\begin{array}{c}-3.921 * * * \\
(0.881)\end{array}$ & $\begin{array}{c}-3.921 * * * \\
(0.951)\end{array}$ \\
\hline Population $X$ & $\begin{array}{c}3.285 * * * \\
(0.612)\end{array}$ & $\begin{array}{c}3.285 * * * \\
(0.661)\end{array}$ & $\begin{array}{c}2.959 * * * \\
(0.569)\end{array}$ & $\begin{array}{c}2.959 * * * \\
(0.578)\end{array}$ \\
\hline Civil Liberties $X$ & $\begin{array}{c}0.175 \\
(0.265)\end{array}$ & $\begin{array}{c}0.175 \\
(0.241)\end{array}$ & $\begin{array}{c}0.173 \\
(0.193)\end{array}$ & $\begin{array}{c}0.173 \\
(0.193)\end{array}$ \\
\hline GDP per capita $X$ & $\begin{array}{c}3.125 \\
(6.914)\end{array}$ & $\begin{array}{c}3.125 \\
(5.794)\end{array}$ & $\begin{array}{c}2.080 \\
(5.347)\end{array}$ & $\begin{array}{c}2.080 \\
(5.170)\end{array}$ \\
\hline GDP per capita $X 2$ & $\begin{array}{l}-0.438 \\
(1.125)\end{array}$ & $\begin{array}{l}-0.438 \\
(0.916)\end{array}$ & $\begin{array}{l}-0.317 \\
(0.849)\end{array}$ & $\begin{array}{l}-0.317 \\
(0.826)\end{array}$ \\
\hline Portion Muslim & $\begin{array}{c}0.674 \\
(0.448)\end{array}$ & $\begin{array}{c}0.674 \\
(0.425)\end{array}$ & $\begin{array}{c}0.558 \\
(0.424)\end{array}$ & $\begin{array}{c}0.558 \\
(0.435)\end{array}$ \\
\hline Population $Y$ & $\begin{array}{c}0.146 \\
(1.565)\end{array}$ & $\begin{array}{c}0.146 \\
(1.640)\end{array}$ & $\begin{array}{l}-0.433 \\
(1.432)\end{array}$ & $\begin{array}{l}-0.433 \\
(1.449)\end{array}$ \\
\hline Civil Liberties $Y$ & $\begin{array}{c}-0.414 * * * \\
(0.151)\end{array}$ & $\begin{array}{c}-0.414 * * * \\
(0.147)\end{array}$ & $\begin{array}{c}-0.500 * * * \\
(0.138)\end{array}$ & $\begin{array}{c}-0.500 * * * \\
(0.143)\end{array}$ \\
\hline GDP per capita $Y$ & $\begin{array}{c}0.276 \\
(0.358)\end{array}$ & $\begin{array}{c}0.276 \\
(0.360)\end{array}$ & $\begin{array}{r}-0.0581 \\
(0.328)\end{array}$ & $\begin{array}{r}-0.0581 \\
(0.332)\end{array}$ \\
\hline Constant & $\begin{array}{c}-25.90 * * \\
(10.85)\end{array}$ & $\begin{array}{c}-25.90 * * * \\
(9.991)\end{array}$ & $\begin{array}{c}-16.23 * * \\
(8.122)\end{array}$ & $\begin{array}{c}-16.23^{* *} \\
(7.966)\end{array}$ \\
\hline Pseudo R_square & 0.25 & 0.25 & & \\
\hline$N$ & 120 & 120 & 120 & 120 \\
\hline
\end{tabular}


Fig1. Justification Across Source Countries

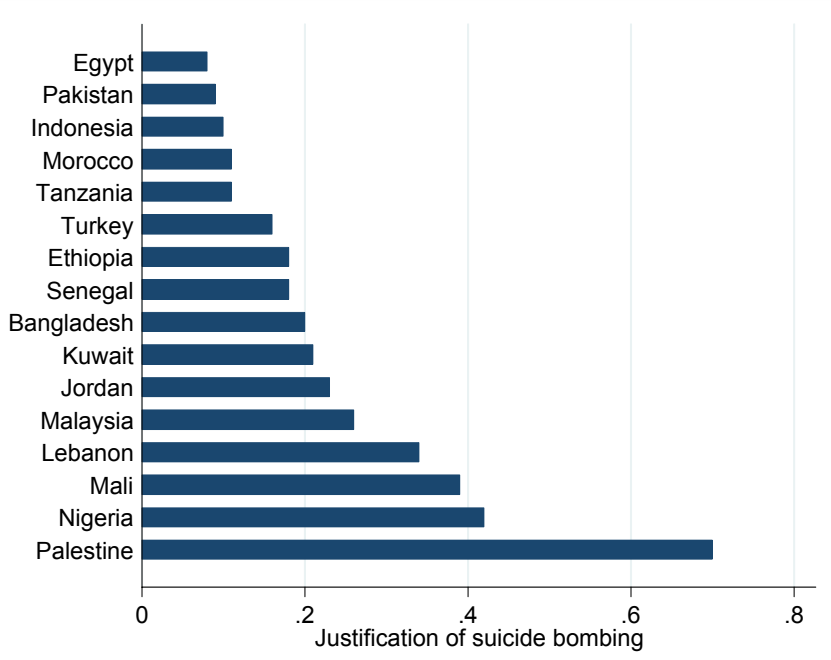

Fig2. Justification and Unfavorable Opinion of X towards $\mathrm{Y}$

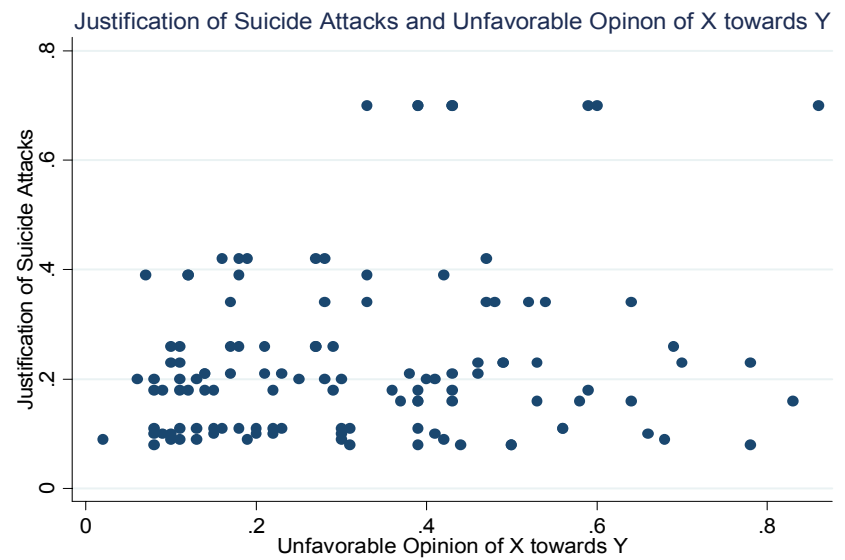

Fig3. Justification and Unfavorable Opinion (normalized by the unfavorable opinion towards Japan)

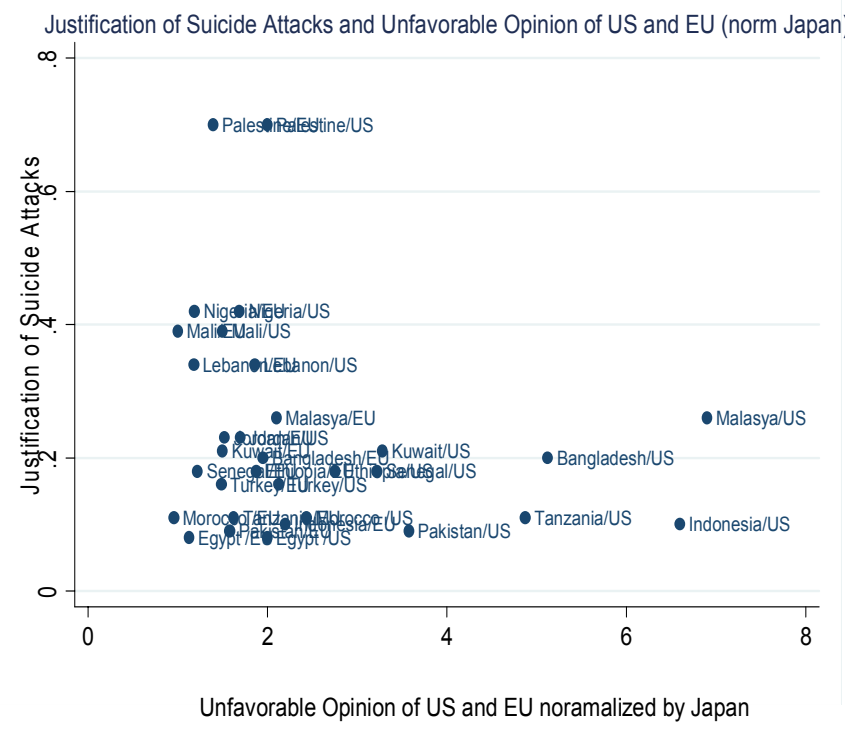


Fig4. The Effect of Increasing Justification by

One Standard Deviation

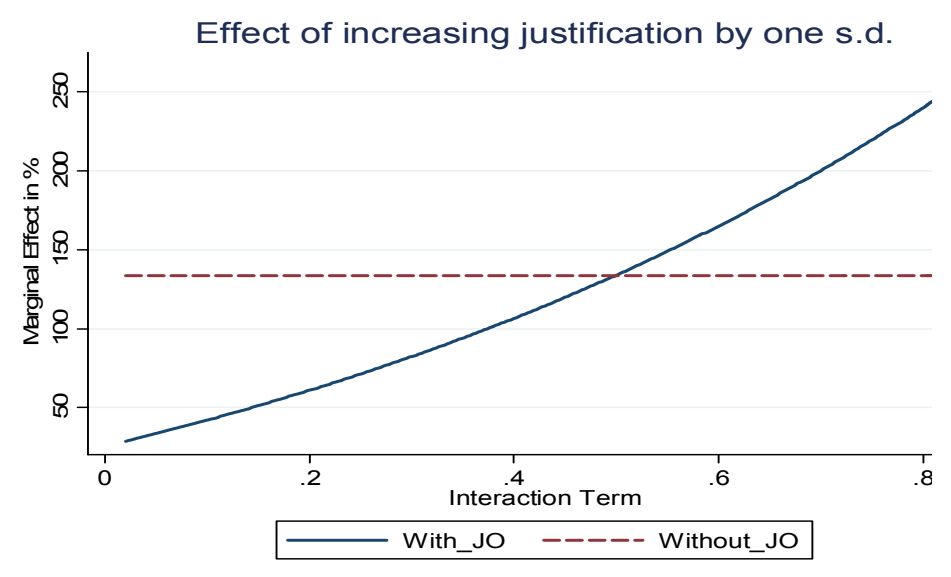

$\mathrm{JO}$ is interaction term.

Fig5. The Effect of Increasing Unfavorable Opinion by One Standard Deviation

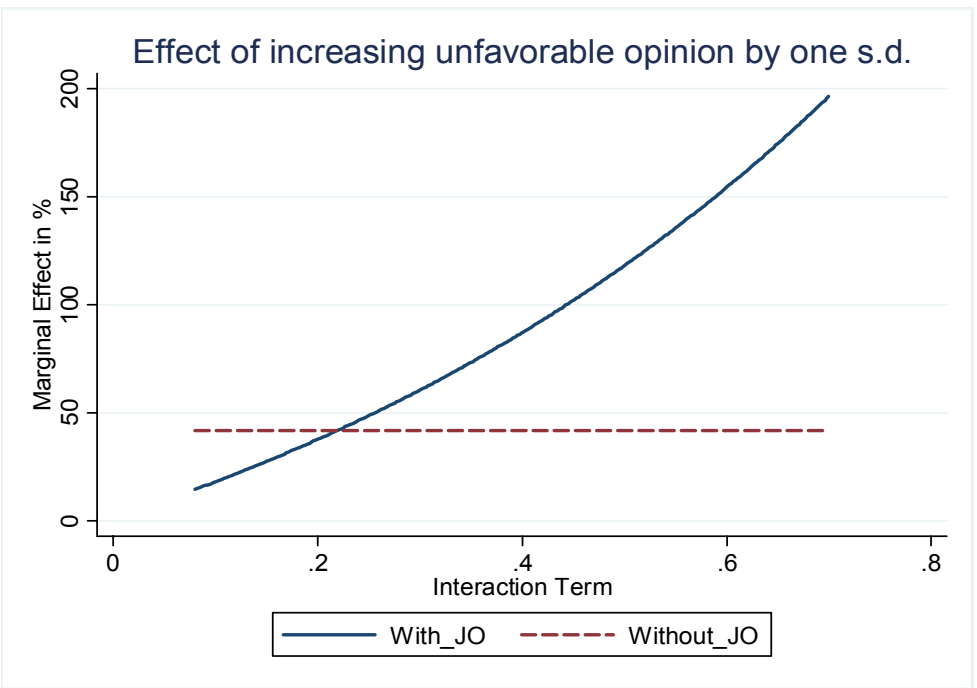




\section{Appendix 2.}

\begin{tabular}{|l|l|l|}
\hline \multicolumn{2}{|c|}{$\begin{array}{l}\text { Pair wise t-test of Justification } \\
\text { by Gender (Female - Male) }\end{array}$} \\
\hline Country & t-stat & v- \\
value \\
\hline Mali & 0.064 & 0.949 \\
Senegal & $\mathbf{1 . 8 6 9}$ & $\mathbf{0 . 0 6 2}$ \\
Nigeria & $\mathbf{3 . 1 2 3}$ & $\mathbf{0 . 0 0 2}$ \\
Bangladesh & 0.463 & 0.643 \\
Malaysia & 1.336 & 0.182 \\
Tanzania & 0.204 & 0.838 \\
Ethiopia & 0.589 & 0.556 \\
Kuwait & 1.018 & 0.309 \\
Turkey & $\mathbf{2 . 7 3 4}$ & $\mathbf{0 . 0 0 6}$ \\
Palestine & 1.332 & 0.183 \\
Jordan & 0.808 & 0.419 \\
Lebanon & 1.016 & 0.31 \\
Indonesia & $\mathbf{2 . 1 4 5}$ & $\mathbf{0 . 0 3 2}$ \\
Egypt & 1.066 & 0.287 \\
Morocco & $\mathbf{6 . 8 6 8}$ & $\mathbf{0}$ \\
Pakistan & $\mathbf{3 . 8 6 9}$ & $\mathbf{0}$ \\
\hline
\end{tabular}

\begin{tabular}{|c|c|c|}
\hline Country & t-stat & $p$-value \\
\hline Mali & -2.367 & 0.018 \\
\hline Senegal & -0.714 & 0.475 \\
\hline Nigeria & 0.581 & 0.561 \\
\hline Bangladesh & 2.112 & 0.035 \\
\hline Malaysia & 0.222 & 0.824 \\
\hline Tanzania & 1.035 & 0.302 \\
\hline Ethiopia & 1.324 & 0.187 \\
\hline Kuwait & -1.345 & 0.179 \\
\hline Turkey & -1.124 & 0.261 \\
\hline Palestine & -0.709 & 0.479 \\
\hline Jordan & 2.024 & 0.043 \\
\hline Lebanon & 0.401 & 0.688 \\
\hline Indonesia & 0.821 & 0.412 \\
\hline Egypt & 0.642 & 0.521 \\
\hline Morocco & 0.067 & 0.947 \\
\hline Pakistan & -0.166 & 0.868 \\
\hline
\end{tabular}




\begin{tabular}{|l|l|l|}
\hline \multicolumn{3}{|c|}{ Pair-wise t-test on Male Population and } \\
Justification by Age \\
(Men Over 40 - Men 40\&Under) \\
\hline Country & t-stat & p-value \\
\hline Mali & 1.674 & 0.095 \\
Senegal & 1.273 & 0.204 \\
Nigeria & 0.579 & 0.563 \\
Bangladesh & 0.789 & 0.43 \\
Malaysia & 0.246 & 0.806 \\
Tanzania & 1.551 & 0.123 \\
Ethiopia & 1.542 & 0.126 \\
Kuwait & 0.959 & 0.339 \\
Turkey & 0.544 & 0.587 \\
Palestine & 0.246 & 0.806 \\
Jordan & 0.856 & 0.392 \\
Lebanon & 0.289 & 0.773 \\
Indonesia & 0.709 & 0.479 \\
Egypt & 0.325 & 0.745 \\
Morocco & 0.195 & 0.845 \\
Pakistan & 0.993 & 0.321 \\
\hline
\end{tabular}

